\title{
ELITE TRADISIONAL DALAM PERGUMULAN SISTEM RELIGIO POLITICAL POWER
}

\author{
Hermanu Joebagio \\ Program Studi Pendidikan Sejarah, FKIP Universitas Sebelas Maret, Surakarta \\ hermanu_joebagio@yahoo.com
}

\begin{abstract}
ABTRACT
This study was aimed to describe: (1) the relation among political groups in the system of religio political power, (2) the political system when dealing with foreign trade organization (VOC), and also (3) the political system encouraging vertical mobility of the Javanese society. This research employed historical methods, and the data were collected from both primary and secondary sources. Meanwhile, the reconstruction of historiography greatly regarded diachronic and synchronic aspects. The results of this study showed that religio political power was produced by the process of Islamization. In that political system, there was equality of position between the rulers and the ulama. The ulama as a representation of the people, bring about the consequence that all public policy must be approved by them. Political system is equal to 'descending of power'. This political system underwent a political change when the central government moved to rural Java, that is changed into nomadism and schizophrenia, because of the strong subordination and repression to the ulama and the opposition groups. The political violence would not build vertical mobility of Javanese people both in education and economic development. Furthermore, this system would face difficulty when deling with the strategy of ex-nihilo by VOC.
\end{abstract}

Key words: religio political power, Islamization, the ulama, ex-nihilo, vertical mobility

\begin{abstract}
ABSTRAK
Studi ini bertujuan untuk mendeskripsikan: (1) relasi antar kelompok politik dalam sistem religio political power, (2) sistem politik itu ketika berhadapan dengan organisasi dagang asing, dan (3) sistem politik itu memacu mobilitas vertikal masyarakat Jawa. Riset ini menggunakan adalah metode sejarah, dan pengumpulan data melalui sumber primer dan sekunder. Sementara itu rekonstruksi sejarah utamakan segi diakronik dan sinkronik. Hasil penelitian menunjukkan bahwa sistem religio political power adalah hasil dari proses Islamisasi. Dalam sistem politik itu terdapat kesejajaran kedudukan antara penguasa dan ulama. Ulama sebagai representasi rakyat memiliki konsekuensi setiap kebijakan publik perlu mendapat persetujuan ulama. Sistem politik mempunyai bentuk yang sama dengan descending of power. Sistem politik ini mengalami perubahan ketika pusat pemerintahan berpindah di pedalaman Jawa, yakni menjadi nomadisme dan schizophrenia, karena kuatnya represi terhadap ulama dan kelompok oposisi. Kekerasan politik itu tidak akan membangun mobilitas vertikal masyarakat Jawa, baik bidang pendidikan maupun pembangunan ekonomi. Bahkan akan menghadapi kesulitan ketika berhadapan dengan strategi ex-nihilo VOC.
\end{abstract}

Kata kunci: religio political power, Islamisasi, ulama, ex-nihilo, dan mobilitas vertikal

tor keberadaan badan dagang kompeni (VOC) yang ingin mendapat konsesi ekonomi dari kerajaan itu. Faktor lain yang memacu lemahnya politik Mataram adalah: (1) tidak tersedianya struktur politik yang memberi ruang keterlibatan politik maupun mobilitas vertikal bagi kelompok sosial masyarakat; (2) 
birokrasi hanya memperkuat kekuasaan raja, dan tidak untuk memberdayakan rakyat; dan (3) kebijakan politik dan ekonomi dirancang tanpa musyawarah antar pejabat istana (Jackson, 1978: 3-22).

Restrukturisasi budaya politik yang dilakukan Sultan Agung (16131645) mengutamakan harmoni dan budaya politik. Harmoni ditujukan untuk membangun relasi antara raja dan ulama, dengan strategi istana sebagai "agen islamisasi" di Jawa (Ricklefs, 1998a: 469-482). Implikasi dari strategi itu adalah istana sebagai pusat pengkajian ilmu agama Islam yang secara moral politik mengokohkan posisi tawar raja (Ricklefs, 1998b: xvii-xix; Mas'ud, 2004: 55-58). Dengan landasan itu Sultan Agung meraih legitimasi politik ulama, sekaligus membangun budaya politik baru. Implikasi dari strategi itu adalah Islam yang dianut cenderung bercorak mistik atau sinkretik. Sifat sinkretik adalah konsekuensi dari masih bertahannya tradisi agama Hindu-Buddha. Corak sinkretik dipersepsikan sebagai 'kearifan yang cerdas' yang membedakan antara syariat agama dan tradisi budaya (Mulders, 1992: 4-19; Ricklefs, 1998b: xvii-xix).

Pada sisi lain, legitimasi politik yang diberikan justru mendomestikasi ulama dan basis massa, bahkan persepsi elite bahwa kekuasaan adalah struktur bersifat pribadi (Moertono, 1985: 17-18). Dalam struktur itu ikatan loyalitas dan tanggung jawab sangat besar, tetapi pada sisi lain elite tidak bisa membedakan antara kepentingan pribadi dan kepentingan publik.

Idealisasi budaya Jawa menekankan rukun, hormat, santun, dan toleransi dalam tata kehidupan. Etika kehidupan itu difungsikan untuk membangun loyalitas, tetapi pada sisi lain, elite tidak konsekuen dengan meletakkan aspek ketidaksederajatan dalam struktur loyalitas (Moertono, 1985: 17-
18). Fenomena ini yang menimbulkan kesenjangan sosial-budaya, sosialekonomi dan sosial-politik antara penguasa dan rakyat. Kontradiksi antara etika dan praktik politik menyebabkan hilangnya moral politik. Rakyat dituntut untuk menyerahkan loyalitas dan kewajiban, tetapi pada sisi lain tidak diberi imbalan perlindungan keamanan, keadilan, maupun kesejahteraan (MagnisSuseno, 1988: 12-15). Dalam konteks ini perlu dipertanyakan bagaimana relasi antar kelompok politik dalam sistem religio political power, bagaimana sistem politik itu berhadapan dengan organisasi dagang asing, dan bagaimana sistem politik itu memacu mobilitas vertikal masyarakat.

Religio political power merupakan sistem kekuasaan yang dipengaruhi oleh konsep agama. Kehadiran Islam memicu perubahan mengenai kebenaran, realitas dan trasendensi politik sebagai konsep dasar kekuasaan (Piliang, 2006: 1). Islamisasi tidak serta-merta mendorong elite politik memilih sistem politik, karena al-Quran tidak menyediakan sistem politik dan sistem ketatanegaraan yang baku (Rais, 2001: 9-12). Rujukan hanya berpijak pada konsep agama terkait dengan dunya-akhirat (dunia-akhirat), din-dawlad (agamanegara), dan umur al-dunya-umur al-din (urusan dunia dan urusan agama). Ketiga konsep politik itu berelasi antara agama dan negara (Syamsudin dalam Gunawan, 2004: 117).

Imajinasi transpolitika keagamaan elite Jawa ketika membangun sistem religio political power adalah menjembatani relasi antara dunia kekuasaan dan dunia produksi dalam kehidupan masyarakat Jawa (Piliang, 2006: 9). Dengan dasar itu, elite Jawa lebih memilih konsep umur al-dunya-umur al-din untuk menumbuhkan perekonomian di kawasan pantai utara Jawa (Maliki, 2004: 50). Kohesi antara konsep politik dan eko- 
nomi berim-plikasi pada struktur sosial yang egalitarian dan kosmopolitan (Abdullah, 1987: 119-120).

Fenomena di atas menunjukkan Islam sebagai alat legitimasi untuk meraih dan mempertahankan kekuasaan politik (Maliki, 2004: 51). Nilai positif yang dipetik dari kohesi politik dan ekonomi adalah tumbuhnya aktivitas hidup kewarganegaraan (civic engagement) dan keterlibatan politik (political engagement) antar kelompok sosial politik (Mujani, 2007: 26-29). Fondasi politik yang dibangun pada awal Islamisasi adalah tumbuh relasi dan konsolidasi antar kekuatan agama, dagang dan kekuasaan (Abdullah, 1987: 119-120).

Fondasi sistem religio political power yang memiliki kesejajaran relasi antara penguasa politik dan tokoh agama mengalami perubahan besar ketika pusat kerajaan berpindah dari pesisir utara Jawa menuju pedalaman Jawa Tengah. Perpindahan merubah relasi politik 'sejajar' menjadi 'subordinasi'. Dengan begitu sistem religio political power berubah menjadi struktur feodalistik dan despotik. Sejumlah ciri dapat ditelusuri: (1) Islam justru dipertahankan sebagai agama yang inklusif; (2) penjinakan terhadap ulama sebagai landasan legitimasi politik; (3) tumbuh aliran orthodox legalistic Islam dan traditional Javanese mysticism dalam masyarakat pedalaman; dan (4) segregasi aliran keagamaan, Islam murni maupun tarekat sengaja diciptakan.

Perpindahan juga berimplikasi pada perubahan struktur relasi sosial berupa pengutuban orientasi politik terindikasi pada dua hal. Pertama, pengutuban orientasi ulama bangsawan dan ulama non-bangsawan (Ali dalam Gunawan, 2004: 246-247). Ulama bangsawan mengikuti garis inklusvisme dan do- mestifikasi, sedangkan ulama nonbangsawan adalah 'tokoh' pemersatu komunitas epistemik secara sosial maupun politik (Latif, 2005: 11). Perbedaan orientasi itu yang sering menimbulkan ketegangan, karena ulama bangsawan berpihak pada penguasa, dan menafikan kepentingan rakyat. Realitas itu yang menyebabkan pemerintah kolonial memandang lingkungan ulama nonbangsawan adalah komunitas yang terpisah dari warganegara Hindia Belanda (Nieuwenhuijse, 1958: 1-31).

Kedua, untuk memperkuat pengutuban itu diciptakan hierarki dan pelapisan sosial dalam istana yang terkait dengan genealogi, derajat, pangkat, dan cara-cara berpakaian dari komunitas istana secara tegas (Darsiti Soeratman, 2000). Realitas di atas justru terbangun budaya sosial yang menyiratkan pembedaan secara tajam antara budaya istana dan budaya masyarakat (Kuntowijoyo, 1987). Pembedaan tersebut akan berpengaruh terhadap aktivitas civic engagement dan political engagement dari warganegara.

Semestinya prinsip religio political power adalah dasar usaha rasional untuk mempertahankan kehormatan dan harga diri kaum Muslim. Namun, sistem yang dimainkan elite politik sering menampilkan wajah domestifikasi dan menekan heteroginisasi. Di sisi lain, ulama non-bangsawan memainkan prinsip doktrinal yang berujung pada pembentukan simbol identitas Muslim. Kontradiksi-kontradiksi itu yang memacu Muslim kehilangan self-reliance (kemandirian), self-sufficiency (swasembada), self defence (swa-pertahanan), dan kreativitas diri (Hanafi dalam Kamdani, 2007: 15). Realitas sosial politik ini menjadikan Muslim tidak memiliki $\mathrm{ca}$ pacity building menghadapi kekuatan asing. 


\section{METODE PENELITIAN}

Metode penelitian yang digunakan adalah metode sejarah. Ada empat langkah dalam metode sejarah, yakni: (1) heuristik, (2) kritik eksternal dan internal, (3) interpretasi, (4) perumusan fakta, dan (5) sajian pemikiran berbentuk rekonstruksi peristiwa (Hockett, 1967: 9; Renier, 1965: 106-110). Implikasi penggunaan metode sejarah tersebut adalah rekonstruksi peristiwa berpijak pada konstruk diakronik (kesinambungan proses waktu) maupun sinkronik (perubahan struktur). Sumber data yang digunakan adalah sumber primer dan sekunder. Sumber primer adalah manuskrip Jawa dan arsip. Sumber sekunder adalah buku, artikel, jurnal, dan hasil penelitian. Aspek diakronik diungkap secara kritis dengan melihat kesinambungan proses waktu, bahkan dilengkapi dengan aspek sinkronik untuk melihat perubahan struktur yang terjadi. Eksplanasinya diperkuat dengan pendekatan teori ilmu-ilmu sosial yang berfungsi untuk mempertajam analisis sejarah (Kartodirdjo, 1992: 120-126; Burke, 1993: 1-21). Karena itu, dalam eksplanasi untuk mengurai keterkaitan sebab-akibat, dan relasi pertalian peristiwa lain yang masuk dalam tema kajian ini. Dengan demikian prinsip eksplanasi dalam konteks ini berupa justifikasi, interpretasi, ketidaksesuaian, atau sejumlah kemungkinan lain tergantung pada aspek yang diketahui maupun yang perlu untuk diketahui.

\section{HASIL DAN PEMBAHASAN}

\section{Relasi dan Kekerasan Politik}

Taufik Abdullah (1987: 120-155) memandang kehidupan politik pada masa Demak mempunyai relasi kesejajaran. Relasi itu dipersonifikasikan adanya peran penguasa, ulama, dan pedagang. Proses relasi itu menghasilkan pranata-pranata, misalnya lembaga istana, pasar dan masjid. Meskipun pranata sosial itu berada di tangan aristokrat, tetapi hal itu untuk menjamin keberlangsungan politik, dan tidak digunakan sebagai hegemoni politik. Relasi antar kelompok politik, baik penguasa, ulama maupun pedagang merupakan peran yang tidak mudah dipisahkan secara tegas. Bahkan Sunan Kudus, Sunan Giri dan Sunan Gunung Jati itu sendiri di samping memerankan sebagai ulama, juga sebagai pedagang besar.

Proses politik itu menunjukkan sifat descending of power dari pada sifat ascending of power (Turner, 2006: 306307). Artinya, proses politik pada descending of power hanya mendapat persetujuan ulama, dan bukan rakyat. Faktor utamanya rakyat memandang ulama adalah wakil mereka dalam menyalurkan suara. Karena itu, proses politik ini hanya menyertakan kelompok penguasa dan ulama. Dalam kasus kekuasaan politik awal kerajaan Islam, proses semacam itu tidak dapat ditafsirkan keberadaan negara pada tangan elite dan ulama. Oleh karena pada awal kekuasaan Kerajaan Islam Demak, kelompok pedagang dan petani lebih suka bersandar pada kebesaran ulama (Graaf, 1986: 203-204). Kedekatan ulama dengan rakyat adalah konsekuensi dari proses Islamisasi dan proses enkulturasi budaya agama kepada masyarakat. Konteks itu yang menumbuhkan sistem religio political power. Realitas politik menunjukkan pada dekade itu sistem politik relatif 'stabil', dan kestabilan politik didorong oleh relasi antar variabel politik, yang meliputi lembaga politik, pembangunan ekonomi yang diperankan pedagang, dan dukungan seluruh elemen politik (Sanit, 1982: 1527). Relasi antara penguasa, ulama dan rakyat justru membentuk kesatuan 
politik.

Perpindahan pusat kerajaan di pedalaman Jawa Tengah justru mendorong ketidakstabilan proses politik, karena domestifikasi terhadap ulama. Pada sisi lain tumbuh relasi negatif antara Sultan Agung dan pedagang Islam pesisir utara Jawa. Untuk itu, ada tiga strategi yang dikembangkan. Pertama, domestifikasi terhadap ulama secara politis tidak menguntungkan (Graaf, 1986: 203-210). Domestifikasi memacu timbulnya tiga kekuatan politik yang berbasis massa, yakni raja, ulama dan bupati. Ricklefs (2002: 27) memandang realitas politik itu sangat disadari Sultan Agung, sehingga dia membangun equilibrium. Ini berarti sistem politik pemerintah pusat tidak boleh terlalu kuat atau terlalu lemah, dan apabila kondisi itu terjadi dapat meruntuhkan pemerintahan. Agar kekuatan politik tetap berjalan harus membangun konsensus antar kekuatan politik.

Kedua, Islam merupakan salah satu simbol yang dipersepsikan Sultan Agung dapat menjaga konsensus politik, serta menjadi landasan tumpuan rekonsiliasi budaya Jawa (Ricklefs, 1998a: 469-482). Konsekuensi dari strategi itu adalah istana dijadikan pusat pengkajian ilmu agama Islam. Strategi budaya itu bermuatan politis untuk meraih legitimasi dari ulama (Azra dalam Gunawan, 2004: 142-143). Dukungan dan legitimasi menjadi pedoman Sultan Agung untuk penataan politik dan ekonomi (Mas'ud, 2004: 5558).

Ketiga, pada dasarnya Sultan Agung membiarkan praktik keagamaan yang mendorong tumbuhnya sinkretisme Islam. Gejala sinkretisme Islam merupakan kondisi wajar sebagai konsekuensi dari bertahannya tradisi Hindu -Buddha. Corak sinkretisme Islam itu merupakan realitas 'arus bawah' yang kemudian menjadi esensi dari budaya masyarakat Jawa (Mulder, 1992: 4-19; Ricklef, 1998b: xvii-xix).

Equilibrium politik menjadi kekuatan dan bingkai sistem religio political power, tetapi sistem politik itu tidak dapat dipertahankan. Kekalahan Sultan Agung dalam penyerbuan ke Batavia menjadi titik balik penerapan sistem despotisme. Perilaku despot tampak dari kebijakan penghancuran pelabuhan di sepanjang pesisir utara Jawa. Perilaku despot digunakannya untuk mengembalikan hegemoni politik. Penghancuran pelabuhan identik dengan penghancuran potensi ekonomi negara, karena pelabuhan merupakan pusat perdagangan yang menjual produk pertanian dan kerajinan. Penghancuran adalah bentuk peniadaan diri tipe masyarakat kota, yang dibangun oleh masyarakat pesisir yang berpijak pada solidaritas Islam (Kartodirjo, 1987: 29-134). Kekerasan politik itu dalam jangka panjang memang dapat mengintegrasikan kekuasaan politik dan ekonomi, tetapi tidak akan dapat mengintegrasikan budaya masyarakat. Proses integrasi budaya yang dilakukan secara politis justru menciptakan segregasi sosial (Vlekke, 1959: 131-132).

Dalam perspektif kekinian, kekerasan politik mengindikasikan sulitnya membedakan antara negara dan kejahatan. Kekerasan politik justru memecah peran ulama dalam dua sayap orientasi politik, yakni: ulama bangsawan yang berada dalam ranah kekuasaan, baik di pusat maupun daerah, dan ulama non-bangsawan yang berada di lingkungan masyarakat pedesaan. Adanya dua kepemimpinan agama secara konseptual berakibat timbul perbedaan peran sosial maupun politik (Abdullah, 1982: 17; Ali dalam Gunawan, 2004: 246-247). Pada dasarnya walau antar mereka berseberangan, tetapi dua kelompok ulama itu saling berhubungan dan memerlukan. 
Ulama non-bangsawan memungsikan diri sebagai counter elite terhadap kebijakan publik yang tak berpihak kepada rakyat (Abdullah, 1987: 134136), bahkan mereka juga berfungsi sebagai cultural broker. Artinya, ulama non -bangsawan berkewajiban memberdayakan masyarakat secara budaya, ekonomi dan politik. Melalui peran ulama tersebut di atas tumbuh khasanah baru dalam perpolitikan abad ke-17 dan 18, yakni tradisi kritik terhadap kebijakan publik yang tidak berpihak kepada rakyat. Untuk menekan kritik ulama non-bangsawan, Sultan Agung menetapkan kebijakan politik pengurungan (policy of containment) yang berperan sebagai alat perdamaian (Steenbrink, 1984: 30). Wujud politik pengurungan adalah pemberian tanah perdikan untuk pengembangan lembaga pesantren. Politik pengurungan bagi Sultan Agung sangat menguntungkan karena: (1) loyalitas dan legitimasi makin meningkat, (2) terjaminnya stabilitas politik dan keamanan, dan (3) memberi jalan bagi Sultan Agung untuk menata kekuatan ekonomi.

Pada sisi lain, kelemahan politik pengurungan adalah terlalu memberi ruang elite politik menjalankan kekuasaannya melampaui batas penilaian moral dan etika. Seluruh kebijakan digerakan oleh kekuatan Ilahiah, gung binathara-bau dendha nyakrawati (agung laksana dewa, pemihara hukum, dan pemegang kekuasaan) merupakan penyimpangan politik keagamaan (Moedjanto, 1987: 28). Kekuatan politik yang digerakan kekuatan Ilahiah yang menafikan pertanggungjawaban menimbulkan nomadism dan schizophrenia politik (Piliang, 2006: 157-177). Kedua faktor di atas saling terkait, karena perubahan fondasi politik yang menafikan pertanggungjawaban adalah sebuah hasrat yang melampaui batas otoritas. Artinya, elite membangun keuntungan politik yang tidak ada lagi kaitannya dengan aspirasi, kepentingan, kebutuhan dan idealisasi masyarakat, ataupun massa politik yang akan diperjuangkan. Pada akhirnya elite politik berwajah ganda yang immoral.

Kekuatan Ilahiah kemudian bermutasi menjadi represif atau kekerasan politik untuk menegakkan kesatuan politik minus kesejahteraan. Kesatuan politik yang dibalut dengan mekanisme kontrol tentu akan menghasilkan keseimbangan politik (Ham, 1982: 6). Dalam perspektif ilmu politik, keseimbangan politik identik dengan stabilitas politik dan keamanan. Hukuman mati terhadap Syech Amongraga yang distigma menyebarkan ajaran sesat, wahdatul wujüd, adalah bentuk kekerasan politik yang ditunjukkan raja kepada rakyat untuk menjamin stabilitas politik dan keamanan.

Kekerasan politik di atas merupakan gambaran nyata bahwa penguasa tidak menghendaki adanya basis massa kuat dalam masyarakat sipil. Basis massa besar dalam masyarakat ditafsirkan sebagai kekuatan tandingan yang mengancam stabilitas politik dan keamanan negara. Kekerasan politik terhadap Syech Amongraga menunjukkan bahwa negara memiliki mata-mata politik dan prajurit yang melakukan kekerasan terhadap warga sipil. Bahkan kekerasan politik itu merupakan cermin dari pertikaian antara aliran agama traditional Javanese misticism (mistik Islam) dan orthodox legalistic Islam.

Sebagian besar masyarakat Jawa memahami semua agama adalah baik dan benar, yang terpenting bagaimana pengamalan agama itu dapat ditujukkan untuk kemaslahatan masyarakat. Sikap terbuka itu dihasilkan oleh pengaruh agama Hindu dan Budha. Ketika sufisme memasuki kehidupan masyarakat Jawa, Islamisasi dikemas secara aktraktif dengan memanfaatkan budaya 
lokal (Azra, 2004: 12-19). Pemanfaatan budaya itu ditengarai Simuh (1999) menimbulkan transformasi dari tasawuf Islam menuju mistik Islam (traditional Javanese misticism). Ajaran mistik adalah inti terdalam yang menjiwai dan mewarnai seluruh aspek kebudayaan Jawa, dan mengakar pada budaya priyayi. Transformasi itu pada periode berikutnya diprovokasi kolonial untuk memperkuat 'politik pemisahan' antara priyayi dan rakyat atau antara ulama birokrasi dan non-birokrasi.

Menurunnya stabilitas politik dan keamanan negara tidak hanya faktor aliran-aliran dalam agama Islam (priyayi, santri dan abangan), karena dalam masa tertentu (Perang Jawa, 1825 -1830) mereka bersatu dalam satu identitas melawan Belanda. Bahkan pada awal abad ke-20 pedagang Muslim, pekerja di kota, para kyai, priyayi, dan petani bergabung dalam gerakan politik Sarekat Islam (Benda, 1985: 42). Dengan begitu, faktor utama yang menurunkan stabilitas politik dan keamanan adalah karena intrik, faksionalisme dan provokasi di lingkungan keluarga istana. Faktor di atas makin diperkuat oleh padatnya hierarki dan pelapisan sosial yang terkait dengan genealogi, derajat, dan kepangkatan. Pada sisi lain, banyak elite istana yang berseberangan dengan mainstream politik pemerintah dipaksa menjadi 'orang agama' atau 'disantrikan' di pesantren yang jauh dari pusat kerajaan (Abdullah, 1987: 144).

Intrik, faksionalisme, provokasi dan menyantrikan elite politik merupakan faktor kontra produktif yang dipersepsikan akan memperbesar kekuatan oposisi. Yang menarik dalam kondisi politik yang kontra produktif itu justru disukai dan dilestarikan oleh badan dagang kompeni. Ketika oposisi kuat, kompeni berbalik membantu raja untuk mendapat konsesi ekonomi dan menjaga equilibrium politik di Mataram
(Ricklefs, 2002: 41-48). Strategi di atas disebut ex-nihilo, yang berfungsi mencegah penggulingan kekuasaan raja.

Descending of power yang berpedoman pada persetujuan elite dan ulama menghadapi kesulitan berhadapan dengan strategi ex-nihilo kompeni, karena elite mengutamakan tertib politik serta membangun struktur politik bersifat konservatif untuk melanggengkan kekuasaan dan melumpuhkan pembaharuan. Akibatnya, pemerintah pusat menjadi sangat lemah berhadapan dengan strategi politik kompeni di atas. Pada sisi lain, pemerintah pusat hanya didukung tentara profesional dan milisi petani. Milisi petani tidak dapat sepenuhnya mendukung tentara profesional karena pada musim penghujan mempersiapkan diri bercocok tanam. Fenomena di atas mengindikasikan milisi petani hanya sebagai pelayan tentara profesional. Pada sisi lain, pemerintah daerah juga memiliki tentara profesional yang dikontrol bupati, bahkan di antara mereka menyewa pasukan profesional dari Bali (Remmelink, 2002: 13-16). Kehadiran pasukan profesional di daerah yang tidak terkoordinasi dapat mengganggu stabilitas politik dan keamanan Mataram.

Menurut Remmelink (2002: 15-16) pasukan profesional di bawah kendali bupati tidak serta-merta merapuhkan stabilitas politik Mataram. Kelemahan sistem politik Mataram adalah tiadanya konsensus politik antar penguasa pusat dan daerah. Ada tiga hal yang harus dipenuhi untuk membangun kemapanan sistem politik: (1) mekanisme kontrol; (2) tersedianya tentara profesional pusat yang tangguh; dan (3) konsensus antar elemen politik untuk menjaga stabilitas politik.

Ketika kondisi politik pusat lemah, timbul subordinasi terhadap ulama. Subordinasi adalah strategi untuk mencegah timbulnya konsolidasi 
antara ulama dan penguasa daerah. Guna menutupi kelemahan pemerintahan dibangun kebesaran simbolik melalui reproduksi babad dan serat sebagai alat propaganda. Babad dan serat dijadikan pembangunan loyalitas, etika dan moral politik. Bahkan babad dan serat dikonversikan dalam ajaran agama Islam untuk meneguhkan loyalitas sebagai basis legitimasi politik (Schumann dalam Bellah, 2000: xxi; Ricklefs, 1998a: 472-474; Sadewa, 1995: 236-248). Bila legitimasi politik kerajaan tradisional melemah akan terjadi perubahan bentuk dari 'negara kontes militer' menjadi 'negara teater' yang didefinisikan sebagai penampilan simbol dan kostum megah (Nordholt, 2005:18). Dengan cara itu identitas dan kebesaran Jawa diperoleh, bahkan elite tradisional menempatkan simbol dan identitas sebagai pijakan politik. Pendapat senada dikemukakan John Pemberton (2003: 80-88) bahwa simbolisme budaya Jawa intinya terletak pada kostum (pakaian beserta pernak-perniknya) yang mengindikasikan kebesaran politik Jawa.

\section{Kemerosotan Politik}

Penyerahan kekuasaan kepada Pangeran Adipati Anom (Amangkurat I, 1645-1677) menimbulkan pro dan kontra. Faktor utama adalah menafikan eksistensi ulama dalam sistem religio political power. Pembunuhan terhadap ratusan (500-600) santri dan ulama di alun -alun Pleret-Kotagede pada 1647, mengindikasikan tidak dibutuhkan lagi legitimasi politik ulama dalam sistem itu (Steenbrink, 30; Kartodirdjo, 1990: 160). Akibatnya, timbul sikap kontra terhadap raja karena: (1) Amangkurat I tidak berwibawa, menindas dan meminggirkan kelompok politik dalam jaringan persekutuan Sultan Agung; (2) phobia terhadap jaringan persekutuan tersebut yang dianggap sebagai gerakan oposisi yang mengancam kekuasaan; dan (3) penyimpangan seksual dalam kehidupan raja (Kartodirdjo, 1990: 159162).

Pemutusan relasi politik antara istana dan ulama berakibat hilangnya basis massa. Ketika Kerajaan Islam Mataram berdiri ulama dan pesantren sebagai kekuatan penyangga, baik sebagai bangunan etika maupun moral politik, juga sebagai kekuatan arbitrase ketika terjadi kebuntuan politik. Realitas politik itu diragukan Amangkurat I, dan memilih pemutusan relasi politik agar perlengkapan magis-religius yang dimiliki tidak 'digerogoti' prinsip egalitarianisme Islam (Magnis-Suseno, 1984: 33). Kebijakan politik dilanjutkan Amangkurat II (1677-1703) dengan menghancurkan pusat keagamaan Giri, Tembayat dan Kajoran. Represi politik terhadap ulama dan lembaga pesantren menunjukkan sekularisme telah tumbuh nyata di Mataram pada akhir abad XVII (Moertono, 1985: 37-39). Dengan demikian nomadism dan schizophrenia juga terjadi dalam kehidupan politik Mataram.

Represi dan peminggiran ulama berakibat hilangnya peran mereka memberi legitimasi, pertimbangan dan penengah konflik. Penyelesaian konflik dilakukan melalui kekerasan. Peminggiran ulama pada masa Amangkurat I dan II justru menampilkan tiga kelompok penekan yang menyelimuti konflik politik Mataram, yakni: (1) aristokrat dan pejabat istana yang berseberangan dengan raja, (2) arisrokrat dan pejabat daerah yang tertekan oleh besarnya upeti yang diserahkan kepada pemerintah pusat, dan (3) ulama kharismatik yang memiliki basis massa. Sinergi antar kelompok penekan itu justru menimbulkan konflik politik secara terus-menerus di Mataram.

Kebuntuan politik menghadapi 
kelompok penekan adalah memacu sebagian besar raja-raja Mataram mencari dukungan kepada pasukan kompeni. Fenomena politik ini menjebak aristokrat dalam kubangan kepentingan pribadi, baik untuk meraih jabatan politik maupun mempertahankan status quo (Sudewa, 1995: 239). Hanya Sultan Agung yang merupakan tokoh terakhir yang bersedia membangun kembali konsensus politik dengan ulama. Dalam hubungan ini konsensus politik ditafsirkan sebagai dasar membangun solidaritas. Karena melalui solidaritas itu antar kelompok politik diikat dalam satu bingkai sistem politik untuk memperkuat tatanan sosial dan politik, baik bidang budaya, ekonomi maupun ketatanegaraan (Bellah, 2000: 55, 210-214). Konsensus dan solidaritas yang tercipta antar kelompok politik dapat menumbuhkan sinergi kepemimpinan antara penguasa dan aparatur-aparaturnya (Maarif, 1996: 39-46; Black, 2006: 28, 282, 320).

Tegaknya sistem politik merupakan aspek penting dalam menjaga stabilitas politik dan keamanan. Benedict Anderson (dalam Clair Holt, 1972: 1 -69) melihat kekuasaan raja bagai cahaya yang memancar dari pusat, dan memberi energi ke seluruh struktur politik kerajaan, sehingga pancaran cahaya yang baik (tidak nomadism dan schizophrenia) dipastikan menjadi alur struktur politik. Struktur itu memberi pengertian, pertama, Mataram adalah negara patrimonial yang dibangun atas kumpulan hubungan patron dan client. Dominasi kekuasaan yang terlalu kuat ataupun terlalu lemah dapat berpengaruh terhadap sistem politik.

Kedua, konsekuensi dari kumpulan patron dan client adalah wilayah kerajaan terbagi dalam lingkaran konsentris yang meliputi nagara (ibu kota), narawita dalem (tanah raja), nagaragung (tanah lungguh), mancanegara (wilayah luar), dan pasisir (wilayah terluar). Wilayah kerajaan yang tersegmentasi itu memaksa raja harus cakap membangun keseimbangan untuk menjaga kesatuan politik di wilayahnya.

Intervensi kompeni justru menimbulkan permusuhan terbuka. Gejala ini mendorong Adipati Anom (putera Amangkurat II) bersimpati kepada Surapati. Yang menarik dari kasus itu adalah Amangkurat II menasehati puteranya agar berpegang pada al-Quran dan al-Hadits, serta meminta nasehat kepada Pangeran Puger dan Cakraningrat II (Sudewa, 1995: 240). Nasehat Amangkurat II dalam pikiran Adipati Anom bersifat kontradiktif, karena alQuran mengajarkan self-capacity building berintikan pembangunan martabat Muslim yang meliputi self-reliance (kemandirian), self-sufficiency (swasembada), self defence (swa-pertahanan), dan kreativitas Muslim (Hanafi dalam Kamdani, 2007: 15). Pada sisi lain, Pangeran Puger dan Cakraningrat II adalah elite istana yang berkolaborasi dengan kompeni, dan penyumbang runtuhnya sistem religio political power.

Kehadiran kompeni di Mataram, meski berada di pinggiran, dan belum sampai pada titik permusuhan kultural. Namun, Schrieke (1957: 97-101) melihat pengaruh kompeni menjadi faktor pemicu rusaknya kesatuan politik Mataram. Sebenarnya kekuatan kompeni tidak terlalu besar, dan kadang mengandalkan kekuatan militer Mataram. Untuk menutupi kelemahan itu kompeni melibatkan diri dalam intrik, faksionalisme, dan provokasi di lingkungan istana. Tindakan itu justru melemahkan sistem kumpulan patron dan client Mataram. Asumsi ini perlu dikemukakan karena kumpulan patron dan client di Mataram adalah kumpulan terbatas yang terdiri aristokrat di dalam dan di luar istana, serta ulama di dalam dan di luar istana. 
Kelemahan sistem sosial Mataram adalah tidak menyertakan client berasal dari masyarakat, yakni pengusaha, pedagang dan perajin. Masuknya mereka dalam client dapat memperkuat tatanan masyarakat organik. Kelompok pedagang dan perajin justru mendapat perhatian ulama, dan umumnya berlindung di bawah ulama kharismatik (Graaf, 1986: 207-208). Marjinalisasi pengusaha, pedagang dan perajin sebagai pelaku ekonomi dapat diamati dalam Serat Wulang Reh dan Suluk Mas Nganten. Serat Wulang Reh karya sastra Paku Buwana IV mengajarkan empat perilaku tercela yakni madat, berjudi, mencuri, dan mencari untung sebanyaknya. Paku Buwana IV dalam serat itu menstigma pelaku ekonomi hanya mencari untung, bahkan membungakan uang melalui gadai. Tindakan itu dipandang tidak memiliki watak sosial. Pada sisi lain, Suluk Mas Nganten menceriterakan keinginan pelaku ekonomi untuk menikahkan anaknya dengan tata cara pernikahan budaya priyayi. Pelaksanaan tata cara itu menimbulkan kelucuan dan keganjilan sepanjang proses pernikahan (Margana, 2004: 213-214).

Perkembangan perpolitikan di Mataram berbanding terbalik dengan realitas politik dalam sejarah Islam di awal Hijriah. Sejarah Islam melukiskan runtuhnya konfigurasi solidaritas kesukuan dan kebangsaan (ashabiyyah) menjadi landasan timbulnya dasar-dasar muru'ah. Dasar-dasar itu lambat laun terkikis dan tercerabut dari akar tradisi dan tatanan kehidupan bangsa Arab, terutama ketika suku bangsa Quraisy memperoleh keberuntungan dan sukses besar dalam dunia perdagangan (Ismail, 2004: 15-16). Rasulullah mereformasi kembali dasar-dasar muru'ah untuk membangkitkan harga diri dan martabat Muslim. Ciri konfigurasi muru'ah adalah: (1) keberanian bertindak, (2) sabar mengatasi persoalan politik, (3) per- sistensi dalam melakukan balas dendam, (4) melindungi orang lemah, (5) melawan tirani politik.

Sebaliknya dinamika politik Mataram hampir tidak ada gerakan reformasi untuk mengatasi krisis politik dan ekonomi. Mereka tidak menempatkan solidaritas sosial, konsensus dan muru'ah sebagai dasar membangun sistem politik. Ibn Khaldun sangat menentang "kehendak" elite politik sebagai landasan bangunan sistem politik (Black, 2006: 28, 282, 320). Di Mataram, "kehendak" itu sebagai landasan bangunan sistem politik yang tampak pada: (1) berkuasa secara otoriter, (2) mengabaikan eksistensi elemen politik sebagai kekuatan politik, dan (3) tak mampu mengendalikan intrik, faksionalisme, dan provokasi di istana. Gejala itu menunjukkan lemahnya pilar konsensus dan kerjasama antar elite politik, sehingga legitimasi politik pun mudah goyah.

Gerakan reformasi Rasulullah berusaha menempatkan kehidupan sosio-budaya, sosio-ekonomi, dan sosiopolitik dalam bingkai solidaritas sosial. Prinsip itu akan menyatukan kelompok sosial dalam ikatan organisasi politik (Bellah, 2000: 210-214; Khaldun, 1986: 157). Ikatan organisasi politik yang dilandasi solidaritas sosial berfungsi untuk membentuk dan memperkuat tatanan baru, menciptakan l'esprit de corp, membangkitkan harga diri dan martabat, serta kedaulatan bangsa. Dalam perspektif sosial, kebijakan Rasulullah itu mempercepat terciptanya integrasi sosial dan budaya masyarakat, karena kelompok sosial dalam masyarakat Arab menyepakati sistem yang dibangun, baik sistem politik, ekonomi, sosial, maupun budaya.

\section{Lemahnya Mobilitas Sosial Vertikal}

Rendahnya gerakan reformasi 
yang dilakukan oleh elite politik Mataram berakibat makin menguatnya tuntutan konsesi ekonomi kompeni. Dengan kata lain, besarnya tuntutan konsesi ekonomi itu adalah akibat lemahnya prinsip tata kelola pemerintah Mataram, serta adanya celah bagi kompeni untuk melakukan tekanan politik. Salah satu indikator yang memacu tekanan politik adalah kekuasaan tradisional berpijak pada 'politik pemisahan', yang tampak pada konteks politik, sosial dan keagamaan (Taylor dalam Cote \& Westerbeek, 2004: 23). Politik pemisahan di atas justru memacu segregasi sosial dan segregasi keagamaan, dan realitas itu menjadi dasar tumbuhnya berbagai benturan sosial. Tumbuhnya segregasi sosial akibat padatnya hierarkhi sosial yang memperlebar pelapisan sosial. Pada sisi lain, tumbuhnya segregasi keagamaan akibat lemahnya Muslim memaknai inklusivisme Islam ketika berhadapan dengan aliran-aliran keagamaan (Soebardi, 1971: 349).

Politik pemisahan justru menumbuhkan struktur the others dalam proses kehidupan sosial masyarakat (Gouda, 2007: 49-51). Struktur the others malahan diperkuat kolonial Belanda untuk melindungi modal usaha mereka yang sudah tertanam dalam industri perkebunan, eksplorasi (perminyakan dan pertambangan), serta industri pabrikan (Niel, 1984: 4-30). Karena itu struktur sosial penduduk Jawa hanya bertumpu pada hierarkhi sosial-politik dan sosialbudaya bagai dua kutub yang berlawanan yang menghasilkan gerakan radikalisme (Gouda, 2007: 51).

Berdirinya Binnenlandschbestuur (pemerintah dalam negeri) dan Inlandsch -bestuur (pemerintah daerah) adalah berintikan pemisahan birokrasi yang ditujukan untuk memutus jaringan loyalitas antara bupati dan raja (Houben, 2002: 19 -40; Leirissa, 1999: 3-4). Gejala politik pemisahan menonjol sejak 1830 yang berfungsi untuk memperkuatkan kedudukan bupati di wilayah konsentris pasisir maupun mancanegara. Gejala politik di atas diperkuat dengan sistem patrimonialisme yang berfungsi membangun relasi permanen antara pemerintah kolonial Belanda dan bupati, serta penguasa kerajaan tradisional (Suminto, 1986: 11-12; Kartodirdjo dalam Antlov \& Cederroth, 2001: 31). Dalam hubungan ini Denys Lombard (2005: 76) melihat ada empat faktor yang memacu putusnya ikatan loyalitas antara bupati dan raja, yaitu: (1) terbentuknya priyayi otonom sebagai penguasa di wilayah konsentris pasisir dan mancanegara; (2) diciptakan strategi perkawinan antar keluarga bupati, dan tidak dengan keluarga istana, untuk memperkuat otoritas kekuasaan bupati; (3) bupati terbebas dari tugas penyediaan pasukan militer untuk pemerintah pusat; dan (4) para bupati juga bergantung pada sumber daya lokal sebagai basis legitmasi politik mereka.

Yang dimaksud sumber daya lokal adalah ulama yang memerankan diri sebagai counter elite terhadap penguasa kerajaan tradisional. Ulama dan basis massa dimanfaatkan bupati untuk memberikan legitimasi politik. Namun, ulama menarik kembali legitimasi itu karena meluasnya tindak tidak terpuji bupati dan birokrat kabupaten yang meminta bagian dari hasil produksi tanam paksa. Bahkan bupati sebagai pengawas politik tanam paksa cenderung menekan buruh tani. Tindakan birokrat dalam pikiran ulama adalah sebagai pelayan pemerintah kafir. Persinggungan politik antara ulama dan bupati justru membuka peluang aristokrat yang disantrikan menjadi 'perekat politik' antara ulama dan kerajaan tradisional. Karena itu dapat disimpulkan bahwa binanegara kerajaan tradisional warisan Mataram tidak pernah mampu menciptakan ikatan lo- 
yalitas secara permanen (Taylor dalam Cote \& Westerbeek, 2004: 10).

Politik pemisahan yang dibangun elite tradisional dan dualisme sistem politik maupun sistem ekonomi berpengaruh terhadap mobilitas sosial vertikal. Furnival (2009) mengasumsikan ada tiga periode kemajuan pekonomian Hindia Belanda, yakni pada 1815-1824; 18301850; dan pada 1850-1870. Tetapi kemajuan ekonomi pada periode itu belum menyentuh stratifikasi sosial terbawah pribumi, karena indikator kemakmuran dan keadilan itu harus dilihat dari variabel moral, sosial, politik dan agama, beserta premis-premis dasar dari variabel itu. Sistem ekonomi tanam paksa (1830) hingga liberalisme (1870) merupakan masa kehancuran subsistensi buruh dan petani, karena tata-kelola pertanian tidak ditujukan untuk menyangga kehidupan lapisan sosial terbawah secara minimal, tetapi justru untuk kepentingan pemenuhan pasaran dunia (Scott, 1989: 4-44; Turner, 2006: 239-240). Petani meskipun tidak akan menuntut hak atas tanah, tetapi mereka berkemampuan untuk mengelola produksi. Persoalannya adalah perpindahan tata-kelola di tangan pengusaha Belanda berakibat kebutuhan minimal petani tidak terpenuhi.

Perubahan subsistensi menimbulkan gejolak sosial yang pada puncaknya memicu gerakan radikal bersandar pada ideologi keagamaan. Ulama, santri dan petani berpandangan hanya Islam merupakan kekuatan dinamik yang dapat merepresi 'politik pertanian' kolonial Belanda. Perubahan subsistensi menunjukkan rendahnya pemahaman politikekonomi elite tradisional mengenai dasar ekonominya sendiri, khususnya bidang pertanian dan perdagangan. Faktor ini menjadi dasar penafsiran, karena sejak awal perkembangan Islam menunjukkan gejala kota. Artinya, masyarakat Muslim di pesisir Jawa su- dah muncul kelas borjuis yang bercorak kosmopolit (Abdullah, 1987: 121-144). Kemampuan dagang yang dimiliki masyarakat Muslim dimanfaatkan raja untuk membangun kekuasaan dan kebesaran, serta melepaskan diri dari cengkeraman kekuasaan Majapahit. Pendapat ini selaras dengan pendapat Benda (1985: 28) bahwa penerimaan Islam oleh elite penguasa diselimuti selubung politik dan ekonomi. Rendahnya kemampuan elite Jawa dalam menghadapi persoalan ekonomi dan politik, karena kebiasaan elite hanya ingin mengetahui aspek luar, dan tidak berkeinginan mendalami relasi kausalitas dari persoalan yang sedang dihadapi (Florida, 2003: 17).

Lemahnya mobilitas sosial vertikal masyarakat dapat dilihat dari indikator rendahnya kesempatan pribumi untuk memasuki pendidikan formal. Menurut Brugmans (dalam Baudet \& Brugmans, 1987: 178-179) pertumbuhan pendidikan kolonial lamban. Dalam regeringsreglement 1854 dikemukakan bahwa pada tahun 1848 pemerintah Belanda menyediakan f 25.000 untuk mendirikan sekolah bagi anak pangreh praja. Biaya itu dapat didistribusikan dan menjangkau Vorstenlanden. Namun, peraturan pemerintah itu tidak dapat dilaksanakan karena belum terbentuk Departemen Pengajaran dan Agama (Veur, 1969: 1). Pada 1850-an sekolah dasar Europesche Lagere School (ELS) didirikan di Vorstenlanden, dan pada 1864 anak-anak pejabat istana memasuki sekolah itu (Adam, 2003: 30; Scherer, 1985: 44). Pada 1852 sekolah guru (Kweekschool) juga didirikan di Surakarta. Sekolah ini tidak diminati anak-anak pangreh praja dan aristokrat, sehingga dua dasawarsa kemudian dipindahkan ke Magelang (Scherer, 1985: 48-53). Anak pangreh praja lebih memilih STOVIA atau THS (Technische Hogere School), karena skala gaji lulusan itu mencapai f 150, sedang- 
kan skala gaji guru antara f 30 hingga $f$ 50. Jumlah anak-anak pejabat pribumi yang memasuki STOVIA sekitar 424 siswa, dan yang lulus sekitar 105 atau 25 $\%$.

ELS setara sekolah dasar yang dikelola zending dan missi. Kehadiran ELS itu menimbulkan perdebatan antara aristokrat, ulama, dan pujangga. Inti perdebatan adalah: (1) sistem pendidikan Barat mempraktekkan nilai sekularisme; (2) sistem pendidikan Barat mempertajam pembedaan sosial, karena yang dapat masuk sekolah itu adalah anak-anak pangreh praja dan aristokrat tradisional. Anak-anak pengusaha batik yang memiliki status ekonomi tinggi terabaikan oleh sistem pendidikan kolonial; (3) di sekolah tidak diajarkan agama Islam dan kebudayaan Jawa. Hal terakhir ini dipandang ulama dan pujangga dapat merusak kepribadian anak -anak pangreh praja dan aristokrat tradisional.

Pemikiran ulama dan pujangga sangat rasional, karena agama Islam dan kebudayaan Jawa adalah inti dari pendidikan moral dan etika. Agama Islam merupakan sistem keyakinan, sedangkan budaya Jawa adalah falsafah hidup leluhur yang diyakini masyarakat Jawa. Alasan lainnya, pada 1833 di Surakarta sudah berdiri Instituut voor de Javaansche Taal (Lembaga Bahasa Jawa), yang dipelopori filolog Belanda J.A. Wilkens, Taco Roorda, dan C.F. Winter (Margana, 2004: 15-44). Meskipun Lembaga Bahasa Jawa dibubarkan oleh pemerintah kolonial pada 1853, dan dipindah di Delft, Belanda, tetapi kajian sastra dan nilai budaya Jawa tetap dilanjutkan oleh Raden Panji, Raden Ngabei (R.Ng) Reksodipuro, dan filolog Eropa (Adam, 2003: 30).

Sistem pendidikan kolonial yang tersekat oleh sistem pelapisan sosial berakibat munculnya kesenjangan sosial yang makin tajam antara rakyat dan pri- yayi. Pada sisi lain, tidak adanya pengajaran agama Islam dan kebudayaan Jawa dalam sistem pendidikan kolonial tersebut merupakan sesuatu yang diciptakan. Dalam pikiran Gouda (2007: 144) pendidikan yang tersekat oleh sistem pelapisan sosial itu justru diciptakan dan dilestarikan, karena melalui tangan anak-anak priyayi pangreh praja itu kepentingan pemerintah kolonial dapat terjembatani. Dengan demikian ditafsirkan bahwa pemerintah kolonial sengaja tidak menghendaki mobilitas sosial vertikal dari masyarakat bawah. Diskriminasi dan ketidakseriusan perencanaan sistem pendidikan kolonial merupakan ironi dari slogan white men's burden (tanggung jawab kulit putih mengadabkan kulit berwarna).

\section{SIMPULAN}

Islamisasi menghasilkan sistem religio political power yang digunakan elite Jawa dalam membangun pemerintahan. Sistem politik ini membangun kesejajaran antar penguasa dan ulama. Ulama sebagai representasi rakyat adalah konsekuensi dari bentuk descending of power, yang berarti setiap kebijakan publik perlu mendapat persetujuan ulama. Bangunan kesejajaran ini mengalami perubahan menjadi subordinasi ketika pusat pemerintahan berpindah di pedalaman Jawa Tengah. Sistem religio political power mengalami nomadism dan schizophrenia, karena adanya subordinasi dan represi terhadap ulama dan tokoh masyarakat. Kondisi ini memacu nomadism dan schizophrenia politik. Situasi politik semacam ini tidak akan mampu berhadapan dengan strategi ex-nihilo kompeni. Perubahan politik yang mengarah pada relasi kekerasan tidak akan memacu mobilitas sosial vertikal masyarakat bawah. Mobilitas terpusat pada konteks politik, dan cenderung 
mengabaikan pembangunan pendidikan dan ekonomi. Dua faktor itu mengakibatkan rendahnya mobilitas sosial vertikal masyarakat.

\section{DAFTAR PUSTAKA}

Abdullah, Taufik. 1987. Islam dan Masyarakat: Pantulan Sejarah Indonesia. Jakarta: LP3ES.

------, "Pola Kepemimpinan Islam di Indonesia: Tinjauan Umum", Prisma, No. 6, Juni 1982.

Adam, Ahmat. 2003. Sejarah Awal Pers dan Kebangkitan Kesadaran Keindonesiaan 1855-1913. Jakarta: Hasta Mitra, Pustaka Utan kayu \& KITLV.

Antlov, Hans \& Sven Cederroth (eds.). 2001. Kepemimpinan Jawa: Perintah Halus, Pemerintahan Otoriter. Jakarta: YOI.

Azra, Azyumardi. 2004. Jaringan Ulama Timur Tengah dan Kepulauan Nusantara Abad XVII dan XVIII: Akar Pembaharuan Islam Indonesia. Jakarta: Prenada Media.

Baudet, H. \& I.J. Brugmans (ed.). 1987. Politik Etis dan Revolusi Kemerdekaan. Jakarta: YOI.

Bellah, Robert N. 2000. Beyond Belief: Menemukan Kembali Agama. Jakarta: Paramadina.

Benda, Harry J. 1985. Bulan Sabit dan Matahari Terbit: Islam Indonesia Pada Masa Pendudukan Jepang. Jakarta: Pustaka Jaya.

Black, Anthony. 2006. Pemikiran Politik Islam: Dari Masa Nabi hingga Masa Kini. Jakarta: Serambi.

Burke, Peter. 1993. History and Social Theory. Ithaca: Cornell University Press.

Cote, Joost \& Loes Westerbeek (eds.). 2004. Recalling the Indies: Kebudayaan Kolonial dan Identitas Poskolonial. Yogyakarta: Syarikat Indonesia.

Florida, Nancy K. 2003. Menyurat yang Silam Menggurat yang Menjelang: Sejarah sebagai Nubuat di Jawa Masa Kolonial. Yogyakarta: Bentang Budaya.

Furnival, J.S. 2009. Hindia Belanda: Studi tentang Ekonomi Majemuk. Jakarta: Freedom Institute.
Gouda, Frances. 2007. Dutch Culture Overseas: Praktek Kolonial di Hindia Belanda 1900-1942. Jakarta: Serambi Ilmu Semesta.

Graaf, H.J. de. 1986. Puncak Kekuasaan Mataram: Politik Ekspansi Sultan Agung. Jakarta: Pustaka Grafitipers.

Gunawan, Asep (ed.). 2004. Artikulasi Islam Kultural: Dari Tahapan Moral ke Periode Sejarah. Jakarta: Raja Grafindo Persada.

Ham, Ong Hok, "Kepemimpinan dalam Sejarah Indonesia", Prisma, No. 6, Juni 1982.

Hockett, Homer Carey. 1967. The Critical Methods in Historical Research and Writing. New York: The Macmillan.

Holt, Claire (ed.). 1972. Culture and Politics in Indonesia. Ithaca: Cornell University Press.

Houben, Vincent J.H. 2002. Keraton dan Kompeni: Surakarta dan Yogyakarta 18301870. Yogyakarta: Bentang Budaya.

Ismail, Faisal. 2004. Pijar-Pijar Islam: Pergumulan Kultur dan Struktur, Yogyakarta: LESFI.

Jackson, Karl D. \& Lucian W. Pye (eds.). 1978. Political Power and Communication in Indonesia. California: University of California Press.

Kamdani (peny.). 2007. Islam dan Humanisme: Aktualisasi Humanisme Islam di Tengah Krisis Humanisme Universal. Yogyakarta: Pustaka Pelajar.

Kartodirdjo, Sartono. 1987. Pengantar Sejarah Indonesia Baru 1500-1900: Dari Emporium sampai Imperium. Jakarta: Gramedia.

1990. Sejarah Pergerakan Nasional, dari Kolonialisme sampai Nasionalisme. Jakarta: Gramedia. --. 1992. Pendekatan Ilmu Sosial dalam Metodologi Sejarah. Jakarta: Gramedia.

Khaldun, Ibn. 1986. Muqaddimah. Jakarta: Pustaka Firdaus.

Kuntowijoyo. 1987. Budaya dan Masyarakat. Yogyakarta: Tiara Wacana.

Latif, Yudi. 2005. Inteligensia Muslim dan Kuasa: Genealogi Inteligensia Muslim Indonesia Abad ke-20. Bandung: Mizan.

Leirissa, R.Z., “Negara Kolonial Hindia Belanda: Tahapan Awal Perkembangan Kenegaraan di Indonesia", Maka- 
lah Seminar Nasional Negara dalam Sejarah Indonesia: Reinterpretasi dan Redefinisi terhadap Arti Integrasi Bangsa, Universitas Indonesia, Jakarta, 31 Agustus 1999.

Maarif, Ahmad Syafii. 1996. Ibn Khaldun dalam Pandangan Penulis Barat dan Timur, Jakarta: Gema Insani Press.

Magnis-Suseno, Franz. 1984. Etika Jawa: Sebuah Analisa Falsafi tentang Kebijaksanaan Hidup Jawa. Jakarta: Gramedia.

Magnis-Suseno, Franz. 1988. Etika Politik: Prinsip-prinsip Moral Dasar Kenegaraan Modern. Jakarta: Gramedia.

Maliki, Zainuddin. 2004. Agama Priyayi: Makna Agama di Tangan Elite Penguasa. Yogyakarta: Pustaka Marwa.

Margana, S. 2004. Pujangga Jawa dan BayangBayang Kolonial. Yogyakarta: Pustaka Pelajar.

Mas'ud, Abdurrahman. 2004. Intelektual Pesantren: Perhelatan Agama dan Tradisi. Yogyakarta: LkiS.

Moedjanto, G. 1987. Konsep Kekuasaan Jawa. Yogyakarta: Kanisius.

Moertono, Soemarsaid. 1985. Negara dan Usaha Bina-Negara di Jawa Masa Lampau: Studi tentang Masa Mataram II, Abad XVI sampai XIX. Jakarta: YOI.

Mulder, Niels. 1992. Individual and Society in Java: A Cultural Analysis. Yogyakarta: Gadjah Mada University Press.

Mujani, Saiful. 2007. Muslim Demokrat: Islam, Budaya Demokrasi, dan Partisipasi Politik di Indonesia Pasca-Orde Baru. Jakarta: Gramedia Pustaka Utama.

Niel, Robert van. 1984. Munculnya Elit Modern Indonesia. Jakarta: Pustaka Jaya.

Nieuwenhuijse, C.A.O. van. 1958. Aspects of Islam in Post-Colonial Indonesia. The Hague and Bandung: W. van Hoeve.

Nordholt, Henk Schulte (ed.). 2005. Outward Appearances: Trend, Identitas, Kepentingan. Yogyakarta: LkiS.

Pemberton, John. 2003. Jawa: On the Subject of Java. Yogyakarta: Mata Bangsa.

Piliang, Yasraf A. 2006. Transpolitika: Dinamika Politik di dalam Era Virtualitas. Yogyakarta dan Bandung: Jalasutra.

Rais, Muhammad Dhiauddin. 2001. Teori Politik Islam. Jakarta: Gema Insani.

Remmelink, Willem. 2002. Perang Cina dan Runtuhnya Negara Jawa 1725-1743. Yogyakarta: Jendela.
Renier, G.J. 1965. History Its Purpose and Methods. New York: Harper \& Row.

Ricklefs, M.C., "Islamising Java: The Long Shadow of Sultan Agung", Archipel, Vol. I, No. 56, 1998 (a).

--. 1998 (b). The Seen and Unseen Worlds in Java 1726-1749: History, Literature and Islam in the Court of Pakubuwana II. Honolulu: Allen \& Unwin, and University of Hawai'i Press.

----------. 2002. Yogyakarta di bawah Sultan Mangkubumi1749-1792. Yogyakarta: Mata Bangsa.

Sanit, Arbi. 1982. Sistem Politik Indonesia: Kestabilan, Peta Kekuatan Politik dan Pembangunan. Jakarta: Rajawali Pers.

Scherer, Savitri Prastiti. 1985. Keselaran dan Kejanggalan: Pemikiran-Pemikiran Priyayi Jawa Awal Abad XX. Jakarta: Sinar Harapan.

Schrieke, B. 1957. Indonesian Sociological Studies. Part Two. The Hague \& Bandung: W. van Hoeve.

Scott, James C. 1989. Moral Ekonomi Petani: Pergolakan dan Subsistensi di Asia Tenggara. Jakarta: LP3ES.

Simuh. 1988. Mistik Islam Kejawen Raden Ngabehi Ranggawarsita: Suatu Studi terhadap Serat Wirid Hidayat Jati. Jakarta: Universitas Indonesia.

Soeratman, Darsiti. 2000. Kehidupan Dunia Keraton Surakarta 1830-1939. Yogyakarta: Yayasan untuk Indonesia.

Steenbrink, Karel A. 1984. Beberapa Aspek tentang Islam di Indonesia Abad ke-19. Jakarta: Bulan Bintang.

Sudewa, Alex. 1995. Dari Kartasura ke Surakarta: Studi Kasus Serat Iskandar. Yogyakarta: Lembaga Studi Asia..

Suminto, H. Aqib. 1986. Politik Islam Hindia Belanda: Het Kantoor voor Inlandsche zaken. Jakarta: LP3ES.

Turner, Bryan S. 2006. Agama dan Teori Sosial. Yogyakarta: Ircisod..

Veur, Paul W. van der. 1969. Education and Social Change in Colonial Indonesia. Athens, Ohio: Center for International Studies, Southeast Asia Program, Ohio University.

Vlekke, Bernard H.M. 1959. Nusantara: A History of Indonesia. The Hague \& Bandung: Van Hoeve. 